\title{
No Room of her Own: Married Couples' Negotiation of Workspace at Home During COVID-19
}

\author{
Ronit Waismel-Manor ${ }^{1}\left[\right.$ D $\cdot$ Varda Wasserman $^{1}\left[\right.$ ] $\cdot$ Orit Shamir-Balderman $^{2}$ \\ Accepted: 31 August 2021 / Published online: 6 October 2021 \\ (c) The Author(s), under exclusive licence to Springer Science+Business Media, LLC, part of Springer Nature 2021
}

\begin{abstract}
The current study examined the right to a professional workspace and separation between private and public within the home as an arena of gendered negotiation and struggle between spouses working from home during the COVID-19 crisis. Using a qualitative, inductive approach based on grounded theory, we conducted in-depth interviews with fifteen professional couples in Israel about their experiences with working from home and the division of labor and space between spouses. Our analysis revealed three key issues related to these experiences: the division of physical workspace between the spouses, the division of work time (compared to home time), and bodily-spatial aspects of the infiltration of workspace into home through the Zoom camera. The patterns described here suggest that the gendered power relations between spouses working from home are reproduced through an unequal negotiation of space and time in the home, so that in practice, men's work was prioritized in spatio-temporal terms, whereas women's workspace and time was more fragmented and dispersed throughout the home and day. These findings illuminate women's right to workspace in the home as an issue of gender equality that has been amplified by the current global pandemic, and how gendered divisions of space and time serve to reproduce the gender order.
\end{abstract}

Keywords Work-family conflict · Gender and space · COVID-19 · Work at home · Gender inequality · dual-earner couples · Space and work $\cdot$ The right to space $\cdot$ Work-family balance $\cdot$ Public and private space

The COVID-19 pandemic was and remains an on-going natural experiment in working from home. Although working from home has become more common and frequently studied in recent years-particularly in terms of its effectiveness and its gendered implications for the ability to combine work and family - the situation where both spouses worked from home was too rare to arouse wide interest. With the COVID-19 lockdowns, working from home has become a widespread phenomenon, but with new attributes: the crisis forced many employees to switch to this work arrangement, with no choice in the matter and no time for preparation. The

Ronit Waismel-Manor

ronitwm@openu.ac.il

Varda Wasserman

vardawa@openu.ac.il

Orit Shamir-Balderman

orits@yvc.ac.il

1 Department of Management and Economics, The Open U. of Israel, 1 University St., Ra' anana, Israel

2 Department of Sociology and Anthropology, The Max Stern Yezreel Valley College, Afula, Israel result was a greater blur of work-family boundaries, as both spouses were often forced to work jointly full time at home, and even do so while their children were quarantined with them. This reality - that will most likely outlast the virushas raised the need for new spatial arrangements within the home that were irrelevant beforehand. Thus, in this paper we ask whether control over the home-space and the ability to separate work from family is a new major arena of negotiation between the spouses as they struggle over their ability to work from home.

Pre-COVID-19 studies on the effect of gender power relations on the ability to separate home from paid work have shown that working from home challenges this dichotomy, and that blurred boundaries between work life and home life is more characteristic of women, while men do better at maintaining the separation (Frenkel, 2008; Sullivan, 2000). These studies, however, have referred mainly to negotiation over the division of household tasks (Bianchi et al., 2012), without referring to space as a resource subject to bargaining between the spouses, or discussing the importance of separation as critical to women's integration in the labor market. The crisis has also led architects and designers to examine 
ways in which the division of domestic space should be modified to meet the requirements of working from home, but the subject has yet to be systematically studied, and in any case, this research direction has hitherto ignored gendered aspects. Juxtaposing the literature on the gendered division of labor inside the family with the literature on the gendered division of space is particularly important, as it may shed light on the less obvious ways in which the gendered division of labor at home and at work is structured and reproduced. This family struggle for professional space has clear gendered aspects, since the spouses do not enter the negotiation from an equal position, but through the local gender power relations, and its results may affect women's ability to work.

Conducted during the COVID-19 crisis in Israel with married couples, where both spouses continued working full-time from home with their children also at home, the present study examined the right to a professional workspace and the ability to separate private from public within the home as a site of gendered negotiation and struggle between the spouses. By adopting the perspective of gendered struggle over the control of space, the study reveals both men and women's perspectives on the division of home-space between work and family needs and examines whether the workspace is divided equally, or whether gender inequality is reproduced through the struggle over it.

\section{Work-Family and the Gendered Division of Labor at Home}

The massive integration of women into the labor force has been considered the gender revolution of the twentieth century, but it has created new patterns of inequality, as their entry into the public sphere (of paid-work) has not been balanced by men's entry into the private (domestic) sphere, resulting in a double burden for women (Goldscheider et al., 2015; Hochschild \& Machung, 2012). Studies have shown that despite some improvement over the past decades, most women still bear most of the burden of unpaid work (Bianchi et al., 2012; Coltrane, 2000; Lachance-Grzela \& Bouchard, 2010). Combined with the growing pressure for intensive parenting (Hays, 1996), this results in significant childcare investment by mothers. Although crises may potentially be a turning point that offer an opportunity for a different interpretation of existing gender arrangements within the family, studies show that during COVID-19 gender inequality has only been exacerbated, increasing the time women devote to domestic tasks (Chamorro-Premuzik \& Ibarra, 2020; Craig \& Churchill, 2020; Hank \& Steinbach, 2021; Yaish et al., 2021).

Work-family researchers explain this inequality in two ways. First, on the micro level, the spouses themselves frame the gender role division at home in essentialist terms, including life circumstances, efficiency, the woman's individual traits or ambitions, and/or the man's inability to perform domestic tasks (Daminger, 2019, 2020; Nyman et al., 2018). This "naturalizes" women's responsibility for domestic work and conceals the structural causes of this inequality. The second, more critical explanation, reveals the way that gender power relations in society shape this inequality, even when both spouses are employed (Davis \& Greenstein, 2013; Lachance-Grzela \& Bouchard, 2010). According to this view, women's disproportional domestic burden is not only the result of gendered power relations, but also a key factor in reproducing them (Becker \& Moen, 1999; Moen \& Yu, 2000; Waismel-Manor \& Levanon, 2017).

Despite the naturalization and structural grounding of the gendered division of labor, it continues to be a topic of daily negotiation between spouses (Geist \& Ruppanner, 2018). The division of housework labor is affected by explicit powerthe ability to directly affect marital decision-making — and by implicit power - the ability to repress controversial issues or avoid conflict around them (Davis \& Greenstein, 2013; Tichenor, 2005). The rich literature on this type of negotiations, however, focuses mainly on the division of tasks and time, whereas domestic space as another key layer of the gendered division of labor has yet to be examined.

An examination of spousal negotiations may profit from applying the theoretical perspective of role spillover, which refers to the ways in which work commitments negatively or positively affect non-work attitudes, abilities, energies, and commitments and vice versa. Although most of the literature focuses on work-to-home spillover, a study on home-to-work spillover shows that women tend to experience its negative impact more than do men, feeling that family requirements do not allow them to properly carry out professional tasks (Keene \& Reynolds, 2005). Studies on working from home have hitherto examined the gendered division of labor between spouses when only one works from home, and demonstrated that whereas women experience disruptions by the children, men tend to devote separate times to their work - with their wives' support (Ammons \& Markham, 2004; Chung \& van der Lippe, 2020; Marsh \& Musson, 2008; Sullivan \& Lewis, 2001). A deeper study relying on this paradigm should expand the examination of home-to-work spillover to include bargaining between spouses who are both working from home around the ability to avoid negative spillover and account for negotiation process over material resources, primarily the division of professional space at home, as it affects their ability to work.

\section{The Gendered Division of Work Space at Home}

Feminist theories on the relation between space and gender view the separation between the public sphere (attributed to masculinity and professionalism) and the private 
sphere (attributed to femininity and family) a key element in reproducing gender inequality (Landes, 1998). Even when this separation became blurred as women began working outside the home, their right to presence in the public sphere remained controversial, leading feminist geographers to claim "the right to the city" for women (Beebeejaun, 2017). This literature focused on safety in public urban spaces (Fenster, 2005), but less so in workspaces specifically (Nash, 2018).

In recent years, the organizational literature has begun examining the gendering of the physical workspace, showing how organizations tend to use organizational and vocational hierarchies as gender segregation mechanisms. For example, the tendency to allocate private and spacious offices to "masculine" or managerial roles, and small, open spaces to "feminine" roles, such as nurses and secretaries (Paliadelis, 2013; Spain, 1993; Wasserman, 2012). Others have shown that women and men do not experience the anonymous and formal workspace in a similar waywomen tend to feel that the space is not "theirs," and not suited for their needs (Hirst \& Schwabenland, 2018; Tyler \& Cohen, 2010; Wasserman \& Frenkel, 2015). However, such gendered analyses have rarely been conducted with respect to the spatial aspect of working from home despite the fact that paid-work at home challenges the distinction between public masculine and private feminine space, raising important questions about the drawing or blurring of boundaries between the them.

The few studies that have examined these questions have shown that working from home involves changes in the material and symbolic nature of domestic space, producing a different spatial map of the household, designed to manage the "traffic of relationships" between the two worlds (Tietze, 2005). Thus, for example, home-workers tend to devote a separate space or room to their work $(\mathrm{Ng}, 2010)$, and often separate it physically, as in shutting the door, in order to protect it against the family, particularly when it includes little children (Tietze \& Musson, 2002; Tietze et al., 2009). Additionally, workspaces at home are often designed to resemble a "normal" workspace ( $\mathrm{Ng}, 2010)$, whereas office workers tend to domesticate their workspace (by hanging photos for example (Wapshott \& Mallett, 2011). When people allocate a separate domestic space for work, it is perceived by all family members as the worker's territory, and the workers tend to consider it desirable if not necessary, although women's tendency to do so is relatively weaker (Sullivan, 2000).

As domestic space becomes visible to all (via Zoom), home-workers use devices (mainly smartphones and laptops) to create the impression of professionalism and of prioritizing work, urging everyone else at home to stay quiet and invisible to their coworkers. In addition, working from home also leads workers to use liminal spaces such as corners, niches and roofs to escape both family and technology
(Shortt \& Izak, 2020). When work from home is carried out using domestic furniture, especially of the more intimate kind (e.g., bed, sofa), the boundaries between the domestic and professional worlds become increasingly blurred, and the body is used as a "battlefield" that negotiates the relations with the various objects. The (professional or domestic) body is the ultimate border object, draining all spatial tensions between the public/work and private/home spheres (Koslowski et al., 2019). Thus, despite the efforts by homeworkers to fortify the spatial boundaries, when work is performed at home, total separation is next to impossible (Surman, 2002). Notably, the negotiation over the possibility of creating such a separation has not yet been studied from a gender perspective.

\section{Method}

The present study employs a qualitative, inductive approach based on grounded theory, suitable for examining the perspectives of individuals operating within a specific set of meanings, thereby illustrating broader social phenomena (Age, 2011; Glaser \& Strauss, 1967; Martin \& Turner, 1986). This approach is particularly appropriate when seeking a novel perspective on a daily phenomenon. The assumption undergirding this approach is that theory should emerge based on the findings or voices arising from the field, such that the researcher's role is to ensure that the findings match the definitions and concepts, and subsequently identify and report recurring themes (Strauss \& Corbin, 1994).

\section{Participants}

In order to examine whether the pandemic was an opportunity to change the traditional gender division of labor or to reproduce gender power relations, we interviewed 15 heterosexual married couples towards the end of the first lockdown in Israel. The study's criteria for inclusion were professional heterosexual married couples working fulltime from home during the lockdown with at least one child under the age of 18 living in the same home. The interviewed couples were upper-middle class professionals working in fulltime jobs, ages 30-57 (see Table 1). All participants had a Masters degree or higher and were in white-collar occupations in the hi-tech industry, academia or government agencies, the very individuals who tend to hold gender egalitarian attitudes and aspire for equal relationships (Chatillon et al., 2018). Furthermore, most lived in spacious houses with a room for each child and with a home-office, albeit infrequently used in the past, so that the issue of the right to this space became particularly significant when both spouses switched to home-work. Finally, due to the fact that their professional roles required availability even when working from home, 
Table 1 Participants' characteristics

\begin{tabular}{|c|c|c|c|c|c|}
\hline Names $^{\mathrm{a}}$ & Age & Gender & Occupation/job & Residence & $\begin{array}{l}\text { Number } \\
\text { of } \\
\text { children }\end{array}$ \\
\hline $\begin{array}{l}\text { Einav } \\
\text { Michael }\end{array}$ & $\begin{array}{l}41 \\
40\end{array}$ & $\begin{array}{l}\mathrm{F} \\
\mathrm{M}\end{array}$ & $\begin{array}{l}\text { Lawyer } \\
\text { Group leader at a startup }\end{array}$ & Apartments in city centers & 3 \\
\hline $\begin{array}{l}\text { Gila } \\
\text { Rubbin }\end{array}$ & $\begin{array}{l}44 \\
43\end{array}$ & $\begin{array}{l}\mathrm{F} \\
\mathrm{M}\end{array}$ & $\begin{array}{l}\text { Engineer } \\
\text { Senior manager }\end{array}$ & Apartments in city centers & 2 \\
\hline $\begin{array}{l}\text { Hadas } \\
\text { Yuval }\end{array}$ & $\begin{array}{l}43 \\
45\end{array}$ & $\begin{array}{l}\mathrm{F} \\
\mathrm{M}\end{array}$ & $\begin{array}{l}\text { Therapist } \\
\text { Manager }\end{array}$ & Private homes in suburb areas & 3 \\
\hline $\begin{array}{l}\text { Linda } \\
\text { Assaf }\end{array}$ & $\begin{array}{l}44 \\
44\end{array}$ & $\begin{array}{l}\mathrm{F} \\
\mathrm{M}\end{array}$ & $\begin{array}{l}\text { Analyst and a manager } \\
\text { Engineer }\end{array}$ & Private homes in suburb areas & 2 \\
\hline $\begin{array}{l}\text { Limor } \\
\text { Itay }\end{array}$ & $\begin{array}{l}43 \\
45\end{array}$ & $\begin{array}{l}\mathrm{F} \\
\mathrm{M}\end{array}$ & $\begin{array}{l}\text { Bank financial adviser } \\
\text { Engineer }\end{array}$ & Private homes in suburb areas & 3 \\
\hline $\begin{array}{l}\text { Mali } \\
\text { Bari }\end{array}$ & $\begin{array}{l}43 \\
43\end{array}$ & $\begin{array}{l}\mathrm{F} \\
\mathrm{M}\end{array}$ & $\begin{array}{l}\text { Lawyer } \\
\text { Analyst }\end{array}$ & Private homes in suburb areas & 2 \\
\hline $\begin{array}{l}\text { Moran } \\
\text { Alon }\end{array}$ & $\begin{array}{l}44 \\
45\end{array}$ & $\begin{array}{l}\mathrm{F} \\
\mathrm{M}\end{array}$ & $\begin{array}{l}\text { Director of a government agency } \\
\text { HR manager }\end{array}$ & Private homes in suburb areas & 3 \\
\hline $\begin{array}{l}\text { Nadin } \\
\text { Eran }\end{array}$ & $\begin{array}{l}35 \\
44\end{array}$ & $\begin{array}{l}\mathrm{F} \\
\mathrm{M}\end{array}$ & $\begin{array}{l}\text { Teacher } \\
\text { Engineer }\end{array}$ & Private homes in suburb areas & 3 \\
\hline $\begin{array}{l}\text { Nofar } \\
\text { Offer }\end{array}$ & $\begin{array}{l}39 \\
40\end{array}$ & $\begin{array}{l}\mathrm{F} \\
\mathrm{M}\end{array}$ & $\begin{array}{l}\text { HR manger } \\
\text { Engineer }\end{array}$ & Private homes in suburb areas & 3 \\
\hline $\begin{array}{l}\text { Orly } \\
\text { Omer }\end{array}$ & $\begin{array}{l}47 \\
46\end{array}$ & $\begin{array}{l}\mathrm{F} \\
\mathrm{M}\end{array}$ & $\begin{array}{l}\text { Faculty member } \\
\text { A manager and an engineer }\end{array}$ & Private homes in suburb areas & 2 \\
\hline $\begin{array}{l}\text { Ravit } \\
\text { Yossi }\end{array}$ & $\begin{array}{l}30 \\
34\end{array}$ & $\begin{array}{l}\mathrm{F} \\
\mathrm{M}\end{array}$ & $\begin{array}{l}\text { Bank financial adviser } \\
\text { Accountant }\end{array}$ & Apartments in city centers & 3 \\
\hline $\begin{array}{l}\text { Rita } \\
\text { Yoav }\end{array}$ & $\begin{array}{l}48 \\
50\end{array}$ & $\begin{array}{l}\mathrm{F} \\
\mathrm{M}\end{array}$ & $\begin{array}{l}\text { Faculty member } \\
\text { Faculty member }\end{array}$ & Private homes in suburb areas & 2 \\
\hline $\begin{array}{l}\text { Vivian } \\
\text { Eddi }\end{array}$ & $\begin{array}{l}55 \\
57\end{array}$ & $\begin{array}{l}\mathrm{F} \\
\mathrm{M}\end{array}$ & $\begin{array}{l}\text { Faculty member } \\
\text { Organizational consultant/Lecturer }\end{array}$ & Private homes in suburb areas & 2 \\
\hline $\begin{array}{l}\text { Vered } \\
\text { Roei }\end{array}$ & $\begin{array}{l}37 \\
44\end{array}$ & $\begin{array}{l}\mathrm{F} \\
\mathrm{M}\end{array}$ & $\begin{array}{l}\text { Teacher } \\
\text { Social worker }\end{array}$ & Private homes in suburb areas & 3 \\
\hline $\begin{array}{l}\text { Zohar } \\
\text { Rom }\end{array}$ & $\begin{array}{l}42 \\
44\end{array}$ & $\begin{array}{l}\mathrm{F} \\
\mathrm{M}\end{array}$ & $\begin{array}{l}\text { HR manager } \\
\text { Chief financial officer }\end{array}$ & Private homes in suburb areas & 4 \\
\hline
\end{tabular}

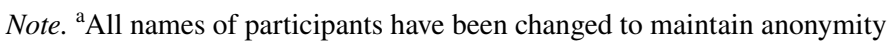

we expected that the couples would have to negotiate their ability to maintain a professional appearance at home as well.

\section{Procedure}

We employed the snowball technique to recruit potential candidates. The interviewees were sampled from all areas in Israel and lived in apartments in city centers and private homes in the suburbs areas. To protect their rights and meet ethical requirements, the participants' identifying information was encoded, only aliases were used, and all data were kept exclusively in the researchers' records. At the end of the analysis, the participants could receive a summary of the findings. The authors of this paper conducted semi-structured in-depth interviews with each participant, via Zoom. Each of the spouses was interviewed individually to ensure openness. After obtaining the participants' informed consent, the interviews took an average of $40 \mathrm{~min}$ to complete (for both women and men). All interviews were recorded and transcribed by a research assistant.
Questions were developed based on reading of the literature on working from home and on household division of labor. However, consistent with grounded theory, after interviewing two couples, we added questions regarding the emergent issues, such as the division of space. The interviewees were asked to relate to identical situations, so that we could evaluate similarities and differences between their perspectives. The interview guide included five parts: (a) demographic questions, such as age, number and age of children, (b) work-related questions, such as occupation, job tenure, commute time, and before and during lockdown questions (e.g., work-hours and perceived productivity), (c) homeworking experience before and during the lockdown, such as routines, location within the home and design of workspace, (d) division of labor between spouses before and during lockdown, including questions about daily routines for childcare and home chores, and (e) questions regarding division of space with their spouse, such as "How do you perceive the experience of working together from home?" 
and "Have you negotiated the use of the various domestic spaces and if so, how?" (see Appendix for interview guide).

\section{Data Analysis}

The data analysis was based on a hermeneutic approach seeking recurring patterns in order to extract meanings (Age, 2011), a dynamic analytic process designed to give meaning, interpretation, and generalization to the phenomenon under study. The data collected in the interviews were analyzed through open coding (Strauss \& Corbin, 1994), and involved sifting, charting, and sorting material by key themes, while enabling new issues and theoretical framings to emerge from the data. While we approached our study with a broad interest in the labor division of married couples, who worked from home during the pandemic, initial analysis of the data revealed new themes that were not predetermined, but were the outcome of an ongoing process that unfolded during the course of the analysis (Charmaz, 2006). These themes were noticed by all three authors, who wrote notes separately on each interview and identified similar descriptions that enabled us to engage in a comparative analysis of the data.

To achieve saturation of the data we followed iterative coding processes between the literature, data, and emergent grounded categories (Marshall \& Rossman, 2016). This process included four stages. First, all transcripts of interviews were coded by each author separately based on 'in vivo' words. We used participants' phrases, terms, and descriptions to generate our first-order concepts, including all comments on participants' negotiations over valuable resources. Second, we compared coded documents and discussed possible conceptual patterns to refine the emerging categories each of us had identified. This systematic process enabled us to frame the bargaining strategies between the spouses in terms of a struggle for the right to professional space, continuity of work-time and embodiment issues related to the entrance of the Zoom camera into home-space. Third, each of us went back to the materials, reread them and mapped all quotes that matched the identified categories in order to confirm that these categories capture the main issues raised by the interviewees. To validate our theoretical conceptualization, we re-read previous literature on work-spaces and the interrelations between space, time and embodiment. Fourth, the findings were sent to a number of participants who had agreed in advance to provide comments and feedback on the initial analysis, thus ensuring validity and trustworthiness.

Overall, the analysis of the themes covered two analytic dimensions: emic analysis that addressed the point of view of the interviewees, grounding the main themes, and etic analysis that addressed the researchers' perspective, informed by the theoretical context (in this case, critical feminist theory; Reinharz \& Davidson, 1992).

\section{Results}

The findings indicated that when the two spouses worked from home, the right to a professional space within the house and the ability to separate this public space from the private domestic sphere became an arena of negotiation between them. This struggle was essentially gendered, affecting the women's ability to integrate equally into the labor market. The negotiation or bargaining was conducted on different levels and in different dimensions. The following three themes represent issues pivotal to that negotiation: the right to space, control of work time, and body and space via Zoom (Table 2).

\section{"The Kids Came in Through the Window": The Right to Space}

One of the key arenas of negotiation between the couples was the struggle for the right to a quiet workspace within the home, which in almost all cases ended with the women giving up on their right for a space of their own. Among almost all of the couples, domestic space was divided unequally. The men found themselves a private and quiet room where they would spend most of the daytime working hours and avoid caring for their children, whereas the women tended to place themselves at the center of the house, in the living or dining room, where they could observe and care for the children during working hours. This echoes studies about workspaces that report men's tendency to occupy a greater share of any given space, or "manspreading" (Bartky, 2015; Trethewey, 1999) — a tendency reproduced also in domestic workspaces. Thus, although most couples defined themselves as adhering to a more or less equal division of labor, in the struggle for space the men's prerogative was taken for granted, and was hardly ever negotiated.

Ziva $(42+4$ children), an HR manager in a hi-tech startup, described how her husband appropriated workspace in the home right at the beginning of the lockdown, after they decided to "stay at home to help each other:"

He had an important event at work that he had to attend, and so he abandoned us. He took calls all day, and from the morning, he entered the RSS [residential secure space-a small protected room in every Israeli apartment]. He conquered the RSS. Makes himself coffee, shutting the door. 'That's it, now I'm here, deal with it.' At a certain point I felt I couldn't take it, I wasn't making any headway [at work]... I tried to be understanding, but wait a minute, I need some too. I think that a lot of it was mainly my pressure, I had to show my bosses that I was working, that I haven't disappeared. The management in my organization is also very-very strict... In the first few 


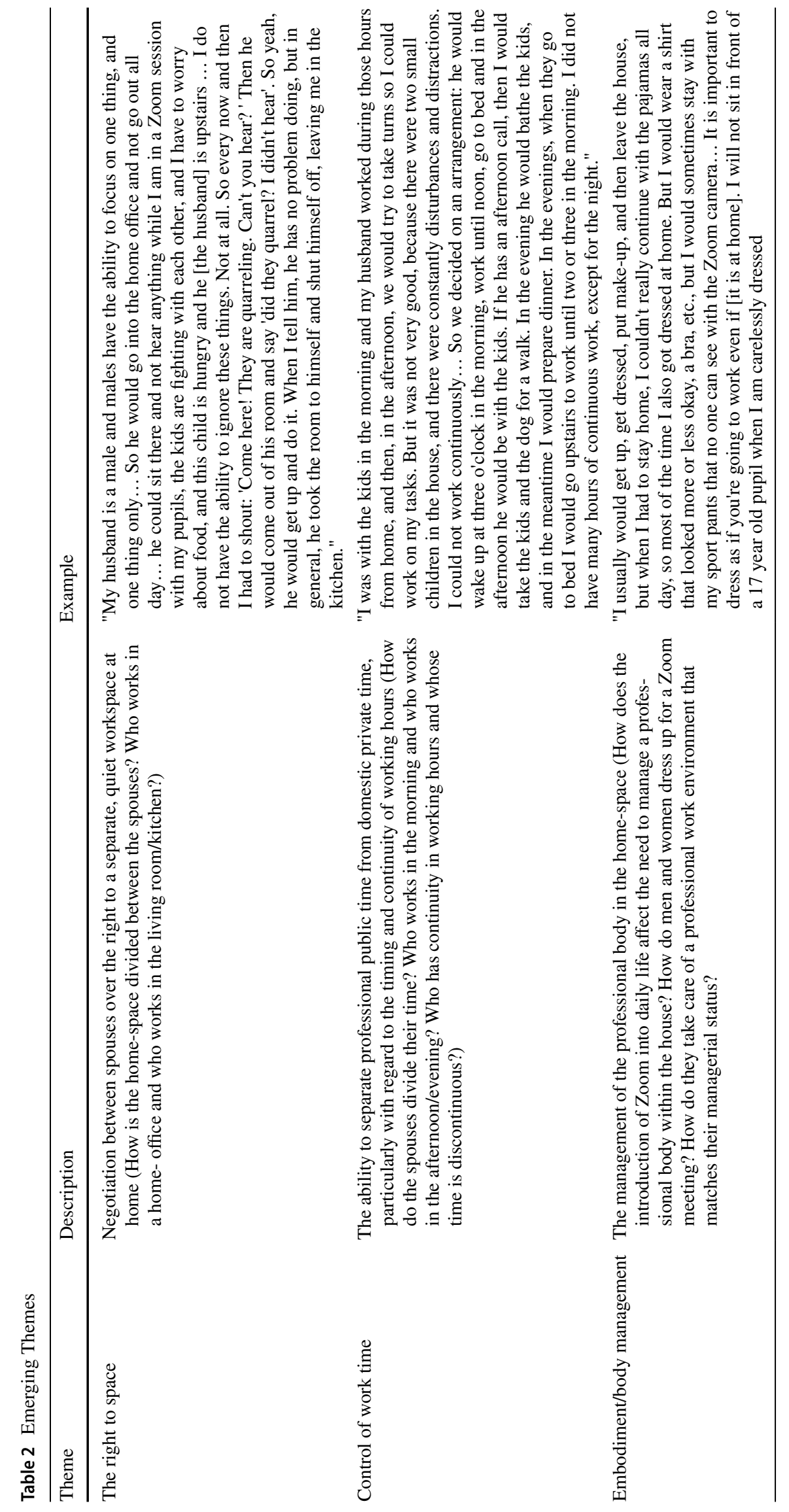


days, I felt I was actually collapsing... I had to figure out where I could draw strengths from.

Ziva uses the militarist terminology of "conquering space" to describe her passive and subordinate stance in the marital negotiation process, despite the fact that it compromised her ability to keep working during COVID19. This struggle - or rather lack thereof - reflects a basic assumption shared by both: not only is his work more important, it is he who is entitled to a quiet professional space of his own. She tries to "be understanding" of her partner's needs, whereas he fails to consider her needs and her right to the space, even though hers is also a senior and highly demanding role in an organization with a "veryvery strict" management. Later on in the interview, she says that only after having failed to deal with the situation, they started negotiating an arrangement that would enable her to work from home as well. Nevertheless, he continued working in the RSS while she worked in the kitchen with the children around her. In the interview with her partner, he never referred to their unilateral negotiation, and justified his "occupation" by saying, "Well, I need it because I'm here all day and I have lots of meetings."

Hadas $(43+3)$, a psychotherapist, uses similar "conquering" terms to describe the unequal division of the domestic workspace:

The phone calls - because these are highly personal conversations on subjects I don't want my children to be exposed to - I always take next to the entrance door.... These are usually unexpected calls, a crisis of some kind that I have to address somehow... I don't have a study or a corner of my own... Once the coronavirus started, everything immediately became concentrated into the house. We have a small study at home, where my husband usually works... Because he has to continuously work all day, he works there. He kind of commandeered that corner, but ever since I started working from home, we began sharing it. It's a desk with a computer, two computers actually, and all the Zoom conversations [are made from there]. It's in the bedroom, and we would actually work in shifts. Two hours for me, and the rest of the day for him \{laughing $\}$... I'd lock the door to keep the kids out. Once, the kids came in through the window in the middle of a meeting.

Hadas describes an arrangement whereby the workspace is allegedly shared, but this division is far from equal. First, she uses the word "commandeered" to indicate that her husband's act was unilateral and forced upon her. Second, she only uses the shared workspace for two hours, her laughter indicating full awareness of the inequality, but also its grudging acceptance-sarcasm or a strategy of reconciling with her quick surrender. Third, even when she is alone in the room and locks it, the kids come in through the window. Later in the interview, Hadas admits that the kids never disturb her partner. Fourth, she clearly has no permanent workspace, and has to migrate between the study in the bedroom and the area near the entrance door, whereas her partner has a permanent workspace where he spends most of the workday.

The "nomad" status described by Hadas is described in even harsher terms by Vivian, an academic staff member $(55+2)$ :

I have a large and very comfortable study at home, and ordinarily I work there. But now with COVID19, the kid has taken over this space and he wants to shut the door and have some peace and privacy, so I gave up and moved to the living room. This way I'm actually in the middle of the house, and everything passes through me. [But] I don't have any privacy. And it was also somehow convenient for me to be at the center of things... So somehow this mess is all my fault... Right at the beginning, the kid was sitting next to me, which was a huge mistake. It was in order to help him out with the school assignments, because he had a terrible time with the Zoom... My partner goes down to the basement and spends long hours there, he spends most of his day there. He doesn't help the kid with his homework, so he manages to work there far from the shouting upstairs... And now the entire living room is a mess because of me, because I have lots of books that I need, so I made this shopping basket and I go with it everywhere. With this basket, I'm like a vagrant inside my house... I'm really in a kind of mobile study.

In Vivian's case, although both spouses can enjoy privacy at home, the woman chooses to be in the middle of the house, sacrificing her work to help the child with his studies. She gives up on her privacy willingly, because this gives her greater control of what is going on in the house, even if it turns out to be a "mistake" in terms of the family spatial relations. The result, in any case, is that she becomes a "vagrant" unable to concentrate and enjoy the peace and quiet her partner enjoys in the basement. It is also important to note that this is the case despite the fact that Vivian has been the main breadwinner during the lockdown.

Vivian's experience also highlights the complexity involved in the spouses' gendered choices, affected the unequal division of labor that had predated COVID-19. Paradoxically however, in Vivian's case she is supposedly the powerful partner. Moreover, she herself belittles her power and status using the supermarket basket metaphor. And if that were not enough, in the interview with her partner Eddie 
(58, business owner), he appeared completely unaware of her "nomadic" status and the unequal division of space:

There is a spatial division at home. The son usually sits in the living room or study, because he needs the computer for his Zoom sessions. I work from the basement... I prefer the basement because it's quiet... Because everyone's working with the Zoom systems... Luckily, we have the option for each one to work on an almost separate floor, in a different space, so then we don't disturb one another... We don't have strict rules... It's highly variable, dynamic. Both in hours and in space, but I would say I have my room, my peace and quiet.

Q: Don't you share it?

A: No, they don't come down here. Neither of them likes the basement very much...

Eddie is completely unaware of the unequal division of space, perhaps partly because it was not negotiated at all. Vivian had given up on her right without claiming it from her husband. Similar findings also arose in interviews with other women, who preferred working from central locations that allowed them to look after the children, help them with their homework or supervise the house in general: the kitchen island, a study in the gallery overlooking the house, or the living room couch. In all cases, failing to claim her right to space meant that the woman had trouble concentrating on her work, affecting her workplace integration and involvement.

\section{"I Need Some Kind of Continuity": Control of Work Time}

A second marital bargaining arena had to do with the ability to separate professional public time from domestic private time, particularly with regard to the timing and continuity of working hours. Without a room or workspace of their own, many of the women failed to create a continuous workday for themselves, as did their spouses. Those who did negotiate, gave up in advance on their right to that separation, and hence their right to work continuously in standard working hours. Consequently, their work was discontinuous, frequently disrupted by the children, often forcing them to miss workplace events and meetings. Many worked in the afternoons or evenings when their spouses "took over" the children and they could have some peace and quiet. However, as during these hours fewer colleagues were present "at work," their workplace visibility was compromised. At the same time, they felt they were losing control over their time management.

It's unbearable, having everyone here... I'm only waiting for them to leave, I need my peace... and [the kid] keeps calling and texting me, that pest.... So it's not easy for me to work that way... I need some kind of continuity... (Vivian)

Having given up in advance on a space of her own in her bargaining with her spouse, and having spent all her time in the family space away from the professional space, Vivian's ability to separate also between the work time and family time was affected in a way that damaged her work. In other words, bargaining for time was strongly related to the (lack of) spatial separation between public and private spheres (Grosz, 2018).

The lack of spatial separation meant that many of the women could not devote enough time to their work, and were concerned with their absence from the physical workplace and the Zoom sessions. Many felt that they did not "show enough presence" in the relevant workhours, and felt they were being passed over. Conversely, most of the men reported being able to work continuously and maintain presence at work, and that they enjoyed privacy in the critical times when meetings were held. One of them was Yossi $(34+3)$, a government employee:

I worked more hours... Some of the disruptions were also because $I$ got up to see how the kids were doing ... I don't know why, most of the time it wasn't I who prepared their meals. My wife works regular hours, so she has breaks, and during the breaks she'd take care of them. But I did see that everything was going fine... I also work on projects, so I had to continue doing what I did, so I kept working, I didn't show consideration, you know, my pen didn't drop before I was done, I simply had this commitment.

Like many of the other men in our sample, Yossi managed to work continuously, and when he did take time off work, it was usually on his own initiative. His wife took it upon herself to take care of the children-exclusively — although she too had a demanding job in a financial organization and had to maintain presence at work. In the interview with her, she shared that most of her work-related conversations were made from the bedroom with the kids under the blanket or while preparing lunch. Although Yossi claimed that her job was more amenable to that, in practice she worked just as much as he did, albeit with constant disruptions throughout the day. In fact, their discussions about time sharing were few and ended in silent acquiescence. Thus, although they considered themselves "a modern couple sharing the household tasks," nobody challenged the unequal taken-forgranted division of time despite its effects on the women's work.

Itay $(45+3)$, who works in hi-tech, admitted to being able to work continuously because his wife took care of the children: 
My wife was available here at all times, so it was really easy... But when [she wasn't here], they would text me from the other room, sometimes they knocked on the door. They learned that it's very embarrassing that they enter in their underwear and dad's in a video conference... Still, they didn't bother me much.

Itay admits that he managed to work continuously thanks to his wife taking care of the children, but indicates that when he was made responsible, the kids bothered him less and avoided trespassing into his space, as they did with his wife. Whether this was because their mother would sit next to them in the living room or not, it appears the children also bought into the concept that mother's worktime and workspace were more porous than their father's.

\section{"Dressing Up Like a News Anchor": Body and Space via Zoom}

The third negotiation site was the massive introduction of Zoom into daily life, resulting in the kitchen island and sometimes even the bedroom becoming public meeting rooms, exposed for all to see. On the one hand, revealing the domestic space to one's colleagues could facilitate intimacy, but it could also be experienced as undermining the formality of work life, penetrating the private space and exposing a "vulnerable self" (Shortt \& Izak, 2020). Women, particularly senior managers, became more vulnerable due to being associated with the kitchen or their children. To maintain a professional appearance in private space, the women made an effort to look their best and tidy up the space around them. Orly $(46+2)$, an academic staff member, described it as follows:

When talking to people close to me, I allow myself not to dress up, to leave the laundry behind, even if I feel like dying just by seeing it. This will never happen when I'm with my department director or with students because (a) I try to... maintain separation between me as a professor and me as a private person. (b) I always say a great part of success is orderliness. When I see this behind me, I actually communicate the opposite to my students... When I have a lesson, I prepare in advance, I dress up, I make up, I see to it that my shirt looks good in Zoom... I open the camera to see how the area around me looks, and tidy up if necessary... I think I have to maintain some kind of respect for me... I think it creates a kind of appreciation, professionalism... I'll dress up for a lesson like a news anchor... I'll pick up my hair in a tight hairdo... I give minimal options to talk about my appearance... I represent professionalism, authority... I will also sit up straighter and not lean forward".
Orly has a detailed script for presenting a "professional body" and managing the workspace that invaded her home, suggesting that her marital negotiation expands to other actors: employers and colleagues, and in her case also students. Since her ability to separate public and private space and to present a manageable, professional surrounding is limited due to her unequal power relations with her spouse, she feels her ability to convey a detached professionalism is limited, potentially affecting her image.

To compensate for this disadvantage, she relies mainly on her ability to control her physical appearance and surroundings. The result is a professional body, abstract and sexless, lacking tangibility and mainly family belonging. It relies on separation between home and work life (Acker, 1990). As in previous studies (e.g. Trethewey, 1999), the professional body shifts between the presentation of controlled femininity (e.g. makeup) and the neutralization of any aspect of uncontrolled femininity (e.g. sitting up straight). In the same interview, Orly went on to explain that as a woman, she is more vulnerable to comments about her body. Indeed, her husband, a high-tech engineer, shared: "I don't change my shirt or shave. Maybe I'd avoid wearing a pajama shirt, but I don't wear a dress shirt, because nobody sees anything anyway." Other men in the sample felt the same.

As Orly's quote indicates, the professional body is inseparable from workspace (Grosz, 2018): she does not distinguish between managing her body and managing her domestic surroundings - keeping them both tidy is critical to her professional image and to separating the public and private spheres. Interestingly, this separation is reproduced within the house, with some parts becoming public while others remaining domestic.

Linda $(44+2)$, who works in a biotech company, is also keenly aware of the need to maintain a strict dress code even when working from home:

When I have Zoom meetings, I put on a shirt that's a bit more [formal] ... but sometimes I forget. I have this shocking pink trainer [and] I didn't intend to turn on the camera in one of the meetings... It was such an embarrassing situation, but I couldn't turn off the camera...

As described by Goffman (1978) in his studies of momentary failures in impression management, Linda forgot the rules of the professional body and was seen in an outfit that was inappropriate both because it exposed the domestic sphere and because it signified bursting femininity into the workspace. Her colleagues ignored the impropriety and preferred to see it as a momentary and uncharacteristic slipup. However, Linda felt that if she continued letting the home-space encroach on the workspace, this could affect her career. More importantly, 
Linda's experience illustrates the interrelations between the struggle for space (mostly with the spouse) and the negotiation with colleagues and employers, where it is critical to demonstrate that professionalism is also maintained indoors. The spillover of domestic space through the pink trainer into workspace is risky for Linda. Indeed, she believes additional spillovers could affect her career.

Rita $(48+2)$, a university staff member, uses mainly her hair to mark the transition from domestic to professional space:

For official work meetings I wear just a black, smooth $\mathrm{t}$-shirt... On rare occasions I would put on some make-up. I'll also be more careful with my background, and I loosen my hair... I think I'm prettier this way, and also because at home I'm with my hair up, so I make this kind of distinction between indoors and outdoors... in Zoom it's very hard that you see yourself all the time, so I keep playing around with my hair and with my appearance instead of being in the Zoom session. [Therefore,] I decided to remove my image so that it wouldn't preoccupy me. The conversation becomes easier and you feel less pressure. Without that self-judgment. It's an experience of normalcy.

Rita is no stranger to the standards of a professional feminine body, but she settles for a black shirt and loosening her hair to mark the transition between the domestic and professional spaces, and does it only partially through what is visible to the camera (like many of the men in our sample). Her partial compliance with the professional discipline makes her feel in control of the situation, even though she spends most of her workday in the living room, without a sharper distinction between home and work.

Her smooth hair is seen as a source of strength-"I'm prettier this way"- and by letting it hang down she signifies her exit from home into the professional space, despite the latter being physically within the house. The importance of hair as a marker of social status in the work sphere has already been noted by Kringen and Novich (2018) and others, but in this case, it acts a s symbolic spatial marker that differentiates between the public and the private spheres.

\section{Discussion}

The findings suggest that the invasion of work into the private space during the COVID-19 crisis blurred the boundaries between the public and domestic spheres in a way that made it difficult for both spouses in dual homeworker families to work, especially for women. Many of the couples negotiated the ability to separate the two spheres by controlling space, but due to the gendered taken-for-granted assumptions by both spouses, the men were more successful in securing a separate professional space within the home, and consequently maintained higher presence at work and enjoyed better working conditions. Thus, although it could be expected that the unanticipated move to a dual-homeworking arrangement due to the COVID-19 crisis would challenge existing gendered divisions at home, particularly among upper-middle class families, in practice men's work was prioritized in spatiotemporal terms, while women faced greater difficulties. Both the struggle over space and the gendered use of the body are strategies aimed to cope with the new situation in which both spouses work from home. However, the couples chose to negotiate (or give up negotiation) over space based on gendered, taken-for-granted, culturally prescribed practices.

The contribution of the present study is threefold. First, it adds the spatial perspective to the study of working from home to provide deeper insight into the gendered division of labor at home. Previous studies have referred to the spatial aspect mainly in terms of a physical distinction between the home and the workplace, rather than as a resource negotiated between the spouses under the unique conditions of two home-workers. Examining the division of home-space enables us to reveal hitherto unstudied dimensions of gender inequality in the family and its effects on women's ability to work.

Second, the study addressed a unique embodied form of interrelations between work-to-home spillover and home-to-work spillover. Our study shows that the introduction of Zoom cameras enabled a most invasive form of work-to-home spillover, blurring the boundaries between public and private. Thus, we demonstrated how this blur is manifested in organizational expectations to be constantly available and to maintain a professional, representative bodily appearance even when at home. We reveal that these expectations are gendered and affect the negotiations between the two spouses in regard to their ability to separate the public and private spheres. Furthermore, we show that at the same time, women's needs to maintain a professional body at home and comply with the camera's disciplining involve home-to-work spillover, as their conduct at home affects their work. Thus, the study examines how the professional body in the homespace links the two forms of spillover in a manner yet unstudied.

Finally, the present study used a unique methodology by examining marital power relations through the perspectives of both spouses, providing a deeper, multilayered understanding of the same challenge faced by both. Our findings relate most directly to two main literatures, work-family studies and space and gender, which we elaborate on below. 


\section{Work-Family Studies}

The present findings suggest that in dual-earner families, under conditions of working from home, the negotiation between spouses over the professional space becomes a significant resource in managing work-family relations and the ability to work. Existing studies have shown the gendered division of household tasks as part of the power relations between the two, but under the new conditions created by COVID-19, other resources have been added to the equation, including space. Furthermore, some studies already showed that even before the pandemic, men were better able to separate the professional and private spaces at home (Frenkel, 2008; Sullivan, 2000); however this study adds another theoretical dimension highlighting the significance of control over space as an arena of marital or cohabitating negotiation that affects gender inequality at the workplace.

To examine this negotiation we used a relatively unique methodology in the work-family field that examines the subjective perspectives of both spouses. This revealed not only that women and men treated the resources they struggled over differently, but that compared to their spouses, men showed very little awareness of the unequal power relations involved in their negotiation. Due to that inequality, women's ability to work was compromised as they had to constantly migrate from the professional to the domestic space, where they bore the added burden of caring for the children. This resulted, among other things, in a reduced ability to maintain presence in conventional working hours and a professional appearance. Conversely, by controlling over the professional space, the men could prioritize their work over their family. Thus, the gendered division of domestic space acts as a key barrier to women's integration and promotion in the labor market, thus reproducing gender inequality in society in general.

Another key contribution to the scholarship on workfamily relations has to do with the interaction between the two types of spillover: work-to-family and familyto-work. Despite the years-long understanding that work duties can disrupt family duties and vice versa, most studies have concentrated on the negative effect of work on family and the division of labor within it, while fewer studies examined the latter's influence on the ability to work (Keene \& Reynolds, 2005). The present study highlighted the role of the struggle over domestic space as part of the home-to-work spillover. In particular, this study demonstrated that power migrated from the organization into the home in the form of employer expectations, but more importantly, it indicated that familial power relations migrated to the workplace, as women found it more difficult to meet the expectations for effective and professional homeworking.

\section{Space and Gender}

The current study also demonstrated that the struggle for professional space at home is gendered. Previous spaceand-gender studies, mainly through the feminist geography approach, examined the issue, but focused on women's right to safe urban spaces (Listerborn, 2016; Mitchell, 2003; Whitzman et al., 2013), ignoring gendered struggles within domestic or workspaces. We propose a new perspective on the role of space as a valuable resource in marital relations and in their interactions with the workplace. The present study also challenges the traditional dichotomy between public and private space, not only as it highlights the blurring of their boundaries when working from home, but more importantly by suggesting that the ability to negotiate a clear separation between them is the product of gendered power relations and is critical to the ability to work from home.

The findings indicate that when both spouses work from home, women are much less able to clearly separate the two spheres. Most of the women interviewed for this study had given up their right to professional space at home, and worked from private spaces in a way that exposed their domestic self to the public sphere (via Zoom), compromising their ability to maintain a professional appearance. Indeed, the traditional gendered assignment of the two spheres was interestingly reproduced, as some parts of the house became public (e.g., the study), whereas others remained domestic (e.g., the kitchen).

The negotiation between the spouses occurred in several arenas. First, in terms of the division of physical space, it was found that the workspace at home was appropriated by the men, forcing the women to find other spaces (usually at the center of the house) and convert them into workspaces without privacy. The women even used metaphors of "conquering" and "vagrancy" to describe their experience of having no room of their own for workspace. Second, in terms of the division of time, women enjoyed a peaceful workspace only after the children went to bed, whereas during the conventional working day hours they were unable to separate work from family time as the men did, since they spent most of the time in the living room with their children. This unequal division of time reduced their visibility in the work sphere during the most important hours. Third, the penetration of the workplaces' cameras in the home further blurred the work-home boundaries, mainly because women had no room of their own and therefore had to make an extra-effort to maintain their professional appearance. Since the blurring of the boundaries between the domestic and professional spaces was more threatening for the women than for the men, many were preoccupied by tidying up the space around them while trying to minimize the presence of the home within the virtual workspace. However, the constant 
penetration of their children into the workspace "conquered" by their husbands made this task difficult.

\section{Limitations and Future Research Directions}

These findings provide important insights into the complex negotiations between space and gender among working couples over the right to a professional workspace and the ability to separate between private and public within the home. However, the small sample in this study means that these findings cannot be generalized to all dual home-worker families across all social contexts. Since it appears that the homeworking trend and the penetration of the workplace into the house will continue beyond the present pandemic, future studies should further examine the gendered struggle for space in other contexts as well, across professions and socioeconomic status, as well as different homeworking arrangements. The study was conducted in only one country with a specific gender regime, where commitment to work and parenthood are both highly valued. Comparing Israel to other countries with different gender regimes could enrich our knowledge about homeworking and its gender implications. Particularly interesting would be to compare our findings to situations where the negotiation between the spouses has enabled home-working women to work from a professional space of their own. Last, we offer to deepen our understanding of the gendered pressures the children exert on their parents and its implications for women's right for a professional space.

\section{Practical Implications}

The economic and psychological implications of the situation where one partner works from home have been discussed by policy-oriented researchers, but the implications of both dual-homeworking spouses has been overlooked. We urge organizational policy researchers to expand the research on the gendered nature of negotiations between men and women vis-à-vis professional spaces both within and outside the home to better understand the implications of space on professional images and its affect on women, especially female managers. Another implication of our study for professionals working with couples (e.g., marital counseling) is the need to explore both spouses' right to space, perceptions of their ability to separate between private and public within the home when both must work from home, and to acknowledge disconnections between longstanding gender norms and actual contemporary homeworking patterns as part of dealing with spousal conflict. From a larger policy standpoint, dissemination of information about changing patterns of home-working among dual-earner couples in the media and in the classroom may expedite the alignment between the gendered expectations for the family and the workplace that shape individual relations and striving for gender equality.

\section{Conclusion}

The couples revealed new dimensions of gender inequality as a result of their negotiation over the right for space while both had to work from home. The broad implication of this study is the realization that Israeli women and men do not enter into the negotiation for the right to space on an equal basis, but rather through the local conventional gender regime. This regime means that women give up on their rights in advance - including their right to space - whereas men take these rights for granted. Therefore, the struggle for space at home and for the concealment of the domestic space has become part of the reproduction of the gender order. Women's "vagrancy" within their own home reflects a deep experience of exclusion, not only at work, but also at home, and thus it requires a thorough examination of how to enhance women's feelings of belonging and entitlement to demand a room of their own.

\section{Appendix: Interview Guide}

How old are you?

How many children do you have? What are their ages?

What is the highest education that you have completed?

For how long have you been married?

Have you or one of your family members been sick during the lockdown?

Where do you live?

What is your occupation? What is your job?

How long have you been with the present organization?

Where is your workplace located? How long is your commute?

How many hours do you actually work per week before and during the lockdown?

Did you work from home before the lockdown?

Please describe a typical workday before and during the lockdown.

Where and when in the house do you work? Are you satisfied with the arrangement? Please describe your surroundings.

How productive and efficient do you think you are when you work from home?

What helps and what does not help you work from home?

How many hours/day do you spend in a typical workday on childcare before and during lockdown? And your spouse?

How many hours/day do you spend in a typical workday on housework before and during lockdown? And your spouse? 
Are you satisfied with the division of childcare and home chores between you and your spouse?

Where and when does your spouse usually work from home?

How do you perceive the experience of working together from home?

Have you negotiated the use of the various domestic spaces and if so, how?

Would you like to continue to work from home? Why?

Acknowledgements The authors wish to thank Michal Frenkel for her extremely helpful comments and suggestions. This research was supported by The Open University of Israel's Research Fund (grant no. 41340).

\section{Declarations}

Conflict of interest There are no conflicts of interest.

Human and Animal Participants This research involves human participants and ethical approval was attained from The Open University Ethics Committee.

Informed Consent Informed consent was collected from all participants.

\section{References}

Acker, J. (1990). Hierarchies, jobs, bodies: A theory of gendered organizations. Gender and Society, 4(2), 139-158. https://doi.org/10. 1177/089124390004002002

Age, L. J. (2011). Grounded theory methodology: Positivism, hermeneutics, and pragmatism. Qualitative Report, 16(6), 1599-1615.

Ammons, S. K., \& Markham, W. T. (2004). Working at home: Experiences of skilled white-collar workers. Sociological Spectrum, 24(2), 191-238. https://doi.org/10.1080/02732170490271744

Bartky, S. L. (2015). Femininity and domination: Studies in the phenomenology of oppression. Routledge.

Becker, P. E., \& Moen, P. (1999). Scaling back: Dual-earner couples' work-family strategies. Journal of Marriage and Family, 61(4), 995-1007.

Beebeejaun, Y. (2017). Gender, urban space, and the right to everyday life. Journal of Urban Affairs, 39(3), 323-334. https://doi.org/10. 1080/07352166.2016.1255526

Bianchi, S. M., Sayer, L. C., Milkie, M. A., \& Robinson, J. P. (2012). Housework: Who did, does or will do it, and how much does it matter? Social Forces, 91(1), 55-63. https://doi.org/10.1093/sf/sos120

Chamorro-Premuzik, T., \& Ibarra H. (2020). Why killing the office won't close the gender gap. Fast Company (2020, June 27). https://www.fastcompany.com/90521873/why-killingthe-office-wont-close-the-gender-gap.

Charmaz, K. (2006). Constructing grounded theory: A practical guide through qualitative analysis. SAGE Publishing.

Chatillon, A., Charles, M., \& Bradley, K. (2018). Gender ideologies. In B. J. Risman, C. M. Froyum, \& W. J. Scarborough (Eds.), Handbook of the sociology of gender (pp. 217-226). Springer.

Chung, H., \& van der Lippe, T. (2020). Flexible working, worklife balance, and gender equality: Introduction. Social Indicators Research, 151(2), 365-381. https://doi.org/10.1007/ s11205-018-2025-x
Coltrane, S. (2000). Research on household labor: Modeling and measuring the social embeddedness of routine family work. Journal of Marriage and the Family, 62(4), 1208-1233. https:// doi.org/10.1111/j.1741-3737.2000.01208.x

Craig, L., \& Churchill, B. (2020). Dual-earner parent couples' work and care during COVID-19. Gender, Work and Organization, 28(S1), 66-79. https://doi.org/10.1111/gwao.12497

Daminger, A. (2019). The cognitive dimension of household labor. American Sociological Review, 84(4), 609-633. https://doi.org/ $10.1177 / 0003122419859007$

Daminger, A. (2020). De-gendered outcomes: How egalitarian couples make sense of non-egalitarian household practices. American Sociological Review, 85(5), 806-829. https://doi.org/10. $1177 / 0003122420950208$

Davis, S. N., \& Greenstein, T. N. (2013). Why study housework? Cleaning as a window into power in couples. Journal of Family Theory and Review, 5(2), 63-71. https://doi.org/10.1111/ jftr.12004

Fenster, T. (2005). The right to the gendered city: Different formations of belonging in everyday life. Journal of Gender Studies, 14(3), 217-231. https://doi.org/10.1080/09589230500264109

Frenkel, M. (2008). Reprogramming femininity? The construction of gender identities in the Israeli hi-tech industry between global and local gender orders. Gender, Work and Organization, 15(4), 352-374. https://doi.org/10.1111/j.1468-0432.2008.00398.x

Geist, C., \& Ruppanner, L. (2018). Mission impossible? New housework theories for changing families. Journal of Family Theory and Review, 10(1), 242-262. https://doi.org/10.1111/jftr.12245

Glaser, B., \& Strauss, A. (1967). The discovery of grounded theory. Aldine.

Goffman, E. (1978). The presentation of self in everyday life. Penguin Books.

Goldscheider, F., Bernhardt, E., \& Lappegård, T. (2015). The gender revolution: A framework for understanding changing family and demographic behavior. Population and Development Review, 41(2), 207-239. https://doi.org/10.1111/j.1728-4457. 2015.00045.x

Grosz, E. (2018). Space, time and perversion: Essays on the politics of bodies. Routledge.

Hank, K., \& Steinbach, A. (2021). The virus changed everything, didn't it? Couples' division of housework and childcare before and during the Corona crisis. Journal of Family Research, 33(1), 99-114. https://doi.org/10.20377/jfr-488

Hays, S. (1996). The cultural contradictions of motherhood. Yale University Press.

Hirst, A., \& Schwabenland, C. (2018). Doing gender in the 'new office.' Gender, Work and Organization, 25(2), 159-176. https:// doi.org/10.1111/gwao.12200

Hochschild, A., \& Machung, A. (2012). The second shift: Working families and the revolution at home. Penguin.

Keene, J. R., \& Reynolds, J. R. (2005). The job costs of family demands: Gender differences in negative family-to-work spillover. Journal of Family Issues, 26(3), 275-299. https://doi.org/ 10.1177/0192513X04270219

Koslowski, N. C., Linehan, C., \& Tietze, S. (2019). When is a bed not a bed? Exploring the interplay of material and virtual in negotiating home-work boundaries. Culture and Organization, 25(3), 159-177. https://doi.org/10.1080/14759551.2017.1349128

Kringen, A. L., \& Novich, M. (2018). Is it 'just hair' or is it 'everything'? Embodiment and gender repression in policing. Gender, Work and Organization, 25(2), 195-213. https://doi.org/10.1111/ gwao. 12207

Lachance-Grzela, M., \& Bouchard, G. (2010). Why do women do the lion's share of housework? A Decade of Research. Sex Roles, 63(11), 767-780. https://doi.org/10.1007/s11199-010-9797-z 
Landes, J. B. (1998). Feminism, the Public and the Private. Oxford University Press.

Listerborn, C. (2016). Feminist struggle over urban safety and the politics of space. European Journal of Women's Studies, 23(3), 251-264. https://doi.org/10.1177/1350506815616409

Marsh, K., \& Musson, G. (2008). Men at work and at home: Managing emotion in telework. Gender, Work and Organization, 15(1), 31-48. https://doi.org/10.1111/j.1468-0432.2007.00353.x

Marshall, C., \& Rossman, G. (2016). Designing qualitative research (5th ed.). Thousand Oaks.

Martin, P. Y., \& Turner, B. A. (1986). Grounded theory and organizational research. The Journal of Applied Behavioral Science, 22(2), 141-157. https://doi.org/10.1177/002188638602200207

Mitchell, D. (2003). The right to the city: Social justice and the fight for public space. Guilford Press.

Moen, P., \& Yu, Y. (2000). Effective work/life strategies: Working couples, work conditions, gender, and life quality. Social Problems, 47(3), 291-326. https://doi.org/10.2307/3097233

Nash, L. (2018). Gendered places: Place, performativity and flânerie in the city of London. Gender, Work and Organization, 25(6), 601-620. https://doi.org/10.2307/3097233

$\mathrm{Ng}$, C. F. (2010). Teleworker's home office: An extension of corporate office? Facilities, 28(3/4), 137-155. https://doi.org/10.1108/02632 771011023113

Nyman, C., Reinikainen, L., \& Eriksson, K. (2018). The tension between gender equality and doing gender. Women's Studies International Forum, 68(3), 36-46. https://doi.org/10.1016/j. wsif.2018.01.010

Paliadelis, P. (2013). Nurse managers don't get the corner office. Journal of Nursing Management, 21(2), 377-386. https://doi.org/10. 1111/j.1365-2834.2012.01405.x

Reinharz, S., \& Davidman, L. (1992). Feminist methods in social research. Oxford University Press.

Shortt, H., \& Izak, M. (2020). The contested home. In M. Parker (Ed.), Life after COVID-19: The other side of crisis (pp. 43-52). Bristol University Press.

Spain, D. (1993). Gendered spaces and women's status. Sociological Theory, 11(2), 137-151.

Strauss, A., \& Corbin, J. (1994). Grounded theory methodology: An overview. In N. K. Denzin \& Y. S. Lincoln (Eds.), Handbook of qualitative research (pp. 273-285). SAGE Publishing.

Sullivan, C. (2000). Space and the intersection of work and family in homeworking households. Community, Work and Family, 3(2), 185-204. https://doi.org/10.1080/713658903

Sullivan, C., \& Lewis, S. (2001). Home-based telework, gender, and the synchronization of work and family: Perspectives of teleworkers and their co-residents. Gender, Work and Organization, 8(2), 123-145. https://doi.org/10.1111/1468-0432.00125

Surman, E. (2002). Dialectics of dualism: The symbolic importance of the home/work divide. Ephemera, 2(3), 209-223. http://www. ephemerajournal.org/sites/default/files/2-3surman.pdf
Tichenor, V. (2005). Maintaining Men's Dominance: Negotiating Identity and Power When She Earns More. Sex Roles, 53(3-4), 191-205. https://doi.org/10.1007/s11199-005-5678-2

Tietze, S. (2005). Discourse as strategic coping resource: Managing the interface between "home" and "work." Journal of Organizational Change Management, 18(1), 48-62. https://doi.org/10. 1108/09534810510579841

Tietze, S., \& Musson, G. (2002). When "work" meets "home": Temporal flexibility as lived experience. Time and Society, 11(2/3), 315-334. https://doi.org/10.1177/0961463X02011002008

Tietze, S., Musson, G., \& Scurry, T. (2009). Homebased work: A review of research into themes, directions and implications. Personnel Review, 38(6), 585-604. https://doi.org/10.1108/ 00483480910992229

Trethewey, A. (1999). Disciplined bodies: Women's embodied identities at work. Organization Studies, 20(3), 423-450. https://doi. org/10.1177/0170840699203003

Tyler, M., \& Cohen, L. (2010). Spaces that matter: Gender performativity and organizational space. Organization Studies, 31(2), 175-198. https://doi.org/10.1177/0170840609357381

Waismel-Manor, R., \& Levanon, A. (2017). Time to reconsider work: Dual-earner couples' work-related adaptive strategies and preferences for reduced work hours. International Studies of Management and Organization, 47(4), 336-359. https://doi.org/10.1080/ 00208825.2017.1382270

Wapshott, R., \& Mallett, O. (2011). The spatial implications of homeworking: A Lefebvrian approach to the rewards and challenges of home-based work. Organization, 19(1), 63-79. https://doi.org/10. $1177 / 1350508411405376$

Wasserman, V. (2012). Open spaces, closed boundaries: Transparent workspaces as clerical female ghettos. International Journal of Work, Organization and Emotion, 5(1), 6-25. https://doi.org/10. 1504/IJWOE.2012.048589

Wasserman, V., \& Frenkel, M. (2015). Spatial work in between glass ceilings and glass walls: Gender-class intersectionality and organizational aesthetics. Organization Studies, 36(11), 1485-1505. https://doi.org/10.1177/0170840615593583

Whitzman, C., Legacy, C., Andrew, C., Klodawsky, F., Shaw, M., \& Viswanath, K. (Eds.). (2013). Building inclusive cities: Women's safety and the right to the city. Routledge.

Yaish, M., Mandel, H., \& Kristal, T. (2021). Has the economic lockdown following the Covid-19 pandemic changed the gender division of labor in Israel? Gender and Society, 35(2), 256-270. https://doi.org/10.1177/08912432211001297

Publisher's Note Springer Nature remains neutral with regard to jurisdictional claims in published maps and institutional affiliations. 